\title{
The Influence of Organizational Culture, Training and Communication toward Employee Performance in PT Multi Jaya Samudera
}

\author{
Yusuf Ronny Edward ${ }^{1}$, Calen ${ }^{2}$ \\ ${ }^{1,2}$ Faculty of Economics, Universitas Prima Indonesia, Indonesia \\ yusufronny77@gmail.com
}

\section{Abstract}

This study aims to determine the effect of organizational culture, training and communication on employee performance at PT Multi Jaya Samudera. This research was conducted at PT Multi Jaya Samudera which lasted for 4 (four) months, starting from November 2019 to February 2020. This study uses a quantitative associative method with structural equation modeling (SEM) analysis tools. The sampling technique used is the census sampling. The respondents of this study were all employees of PT. Multi Jaya Samudera as many as 95 people. The instrument used was a questionnaire to collect data from organizational culture, training, communication and employee performance variables. Descriptive analysis results for organizational culture variables, training, communication and employee performance at PT. Multi Jaya Samudera is in the good category. Based on SEM analysis, organizational culture, training and communication have a positive and significant influence on the performance of the employees of PT. Multi Jaya Samudera. The contribution of organizational culture, training and communication variables explained the employee performance variable by 0.749 or $74.9 \%$. The remaining 0.251 or $25.1 \%$ is influenced by other independent variables not examined in this study.
Keywords

organizational culture; training, communication; employee performance

\section{Introduction}

Employees are assets or assets owned by the company to advance its business. The company needs employees who are potential and have good performance. Efforts to improve performance in employees are very important. This is due to the company's success in achieving its goals greatly influenced by the performance of its employees. Therefore, companies need to take actions that support performance improvement such as providing education and training to employees, implementing good organizational culture, and establishing good communication within the company.

Employee performance appraisal at PT. Multi Jaya Samudera is conducted semiannually, where the first semester assessment starts from January to June while the second semester assessment starts from July to December. The performance appraisal involves three parties, namely the employee itself, his direct supervisor and the leadership in his Department / Division. The results of employee performance appraisal in semester two of 2018 and semester one of 2019 can be seen in table 1. 
SIASAT Journal of Social, Cultural and Political Studies, 5 (3) July 2020, 40-50

ISSN: 2721-7469 (Print), 2721-7450 (Online)

Yusuf Ronny Edward, Calen: The Influence of Organizational Culture, Training and Communication toward Employee Performance in PT Multi Jaya Samudera

https://siasatjournal.com/index.php/siasat

Table 1. Employee Performance Assessment Results

\begin{tabular}{|c|l|c|c|}
\hline No & \multicolumn{1}{|c|}{ Score } & $\begin{array}{c}\text { Second Semester 2 } \\
\text { Year 2018 }(\boldsymbol{\%})\end{array}$ & $\begin{array}{c}\text { Second Semester 1 } \\
\text { Year 2019 }(\boldsymbol{\%})\end{array}$ \\
\hline 1 & $\mathrm{~A}(81-100)$ & 4 & 17 \\
\hline 2 & $\mathrm{~B}(71-80)$ & 22 & 30 \\
\hline 3 & $\mathrm{C}(56-70)$ & 58 & 45 \\
\hline 4 & $\mathrm{D}(45-55)$ & 12 & 3 \\
\hline 5 & E $(0-44)$ & 4 & 5 \\
\hline
\end{tabular}

Source: PT Multi Jaya Samudera, 2019

From Table 1 it can be seen that the percentage of employees who get grades A and $\mathrm{B}$ is less than $50 \%$. This data is the main indicator of low employee performance. Employees who get a $\mathrm{C}$ value can be pursued or upgraded to A or B values such as by applying good organizational culture and being accepted by employees, providing training in accordance with the employee's position or job, and increasing communication links in the company both superiors to subordinates and vice versa. Thus, organizational culture, training, communication are factors that can influence employee performance.

Organizational culture is a characteristic that is highly invested by the organization and is an example of an organization to distinguish between one organization and another. Organizational culture contains the values and norms of behavior that are accepted and understood together by members of the organization as a basis for the provisions of the behavior that exists within the organization. Thus, organizational culture can influence the way employees work and behave in the organization. If employees can accept both the organizational culture that is applied, then it can make employees work with comfortable, energetic, and try harder to work to improve performance. Organizational cultural values that are instilled by PT. Multi Jaya Samudera Belawan such as first priority to safety, integrity, customer care, and ownership.

One of the company's goals is to provide training to employees to improve employee performance so that employees can work more optimally. Every training activity carried out must be integrated with the company's human resource strategy if it is to be carried out effectively. With the training, employees can work more efficiently and effectively, so that employee performance can improve. At PT. Multi Jaya Samudera Belawan, training activities are rarely held for employees so that employees especially new employees cannot work properly and optimally.

In addition, to improve employee performance, companies need to establish good communication within the company. This is due to the existence of good communication, so employees can work more optimally, directed, and in accordance with the goals desired by the leadership, so that employee performance can improve. Interwoven communication contained in PT. Multi Jaya Samudera Belawan has not been optimally formed as well as managers with subordinates or fellow colleagues.

Based on the phenomenon of problems that occur in companies, the researchers conducted research on this company with the title "The Effect of Organizational Culture, Training and Communication on Performance.

\section{Review of Literatures}

\subsection{Organizational Cullture}

Organizational culture is a system of shared meanings shared by members of an organization that distinguishes these organizations from other organizations Robbins in 
Sunyoto in Syardiansah (2020). Organizational culture is a pattern of basic assumptions that are found, created or developed by an individual or a particular employee with the intention that government agencies can overcome and overcome problems that arise. Organizational culture becomes a common reference including human resources (HR) in interacting in government agencies.

According to Umam (2012: 129), organizational culture is a system values that are believed and can be learned, can be applied and developed continuously. Sutrisno (2015: 2) argues that organizational culture as a system of values, beliefs, assumptions, or norms that have long been applied, agreed and followed by members of a organization as a code of conduct and solving organizational problems.

From the above understanding, it can be concluded that organizational culture is a value system that is believed and adhered to by members of the organization that can influence the behavior of members in the organization.

According to Sopiah (2008: 128), from an employee's perspective, culture provides guidelines for employees about everything that is important to do. Umam (2012: 131) argues that organizational culture is also called corporate culture, also called work culture because it cannot be separated from the performance of human resources (HR). The stronger the corporate culture, the stronger the drive for achievement.

Thus, it can be explained that organizational culture is important because it is an invisible social force that can influence its members at work.

The indicators of organizational culture in this study are the company values of PT. Multi Jaya Samudera consisting of first priority to safety, integrity, customer care, and ownership.

\subsection{Training}

According to Rivai and Sagala (2011: 212), training is the process of systematically changing employee behavior to achieve organizational goals. Training deals with the expertise and ability of employees to carry out current work. Yani (2012: 82) argues that training for employees is a process of teaching certain knowledge and expertise and attitudes so that employees become more skilled and able to carry out their responsibilities better, in accordance with standards.

From the above understanding, it can be concluded that training is an activity to improve and improve employee work performance so that employees can do their jobs better and in line with the expectations of the leadership

Dessler (2011: 280) also suggests that training is a sign of good management, and the duty of a manager is to avoid the dangers. Having high-potential employees will not guarantee that they will succeed. They must know what you want to do and how you want them to do it. If not, they will do the work their way, not your way or they will improvise, or worse, not do anything productive. Good training is vital.

Thus, it can be seen that training is important to improve work skills, skills and abilities so as to improve employee work.

According to Hamalik (2007: 35), training indicators are as follows:

1. Exercise participants.

The determination of the candidates for training is closely related to the success of the training process which in turn determines the effectiveness of the work.

2. Trainer (instructor)

Trainers play an important role in the smooth and successful training program. That is why an expert coach needs to be chosen.

3. Duration of training. 
The duration of the training is based on considerations about

4. Exercise material.

The training material should be prepared in writing so that it is easy for participants to learn.

5. Form of training

The forms of training used for develop energy skills.

Thus, the five indicators above can be used in assessing the success of the implementation of training activities in the company.

\subsection{Communication}

According to Sopiah (2008: 141), communication is defined as the delivery or exchange of information from the sender to the recipient either verbally, in writing, or using communication tools. Mangkunegara (2013: 145) argues that communication is the process of transferring information, understanding, and understanding from someone, a place, or something to something, place, or someone else.

From the above understanding, it can be concluded that communication is the process of delivering information, ideas, messages from one person to another in the hope that the other person can receive and carry out according to the intended purpose.

According to Mangkunegara (2013: 146), the communication process is a method in which the sender of the message (sender) can deliver his message to the recipient of the message (receiver). Sopiah (2008: 147) also suggested that the importance of communication in relation to work is shown by the amount of time spent communicating on the job.

According to Purwanto (2011: 19-20), to be able to carry out effective communication requires several requirements, namely:

1. Perception.

An intelligent communicator must be able to predict whether the messages to be conveyed can be received by the communicant or not.

2. Accuracy.

In general, the audience has a clear frame of mind. In order for communication to achieve goals, someone needs to express something according to what is in their frame of mind.

3. Credibility.

In communicating, communicators need to have a high level of confidence and optimism that the audience is trustworthy people.

4. Control.

In communicating, the audience will give a reaction or response to the message delivered. Their reaction can make communicators laugh, cry, act, change minds, or be gentle.

5. Harmony.

A good communicator will certainly always be able to maintain a good friendship relationship with the audience so that communication can run smoothly and achieve its goals.

Thus, the above communication requirements can be used as indicators in assessing the effectiveness of communication formed in the company.

\subsection{The Performance}

According to Ronny (2020: 135), performance is a picture of the level of achievement of the implementation of a program of activities or policies in realizing the 
goals, vision and mission of the organization as outlined in the strategic planning of an organization. While Umam (2012: 186) states that performance is a record of the consequences -results resulting in a job function or activity during a certain period related to organizational goals.

From the above understanding, it can be concluded that employee performance is the result or level of success of employees in carrying out the tasks assigned to them to achieve organizational goals.

According to Mangkunegara (2013: 68), employees will be able to achieve maximum performance if he has a high-achieving motive.

Achievement motives that need to be owned by employees must be grown from within themselves apart from the work environment. Whereas Noor (2013: 271) argues that performance is something that appears where individuals are relevant to organizational goals. Good performance is one of the goals of the organization in achieving high work productivity. The achievement of good performance is inseparable from the quality of good human resources.

According to Kaswan (2012: 187), there are six criteria that are used as a basis for assessing performance, including:

1. Quality.

How far / well the process or outcome of carrying out an activity approaches perfection, in terms of conformity with the ideal way of carrying out an activity or meeting the desired objectives of an activity.

2. Quantity.

The amount produced is expressed in terms of dollars / rupiah, the number of units, or the number of activity cycles that have been completed.

3. Timeliness.

How far / whether an activity is completed, or the results produced, at the earliest time desired from the point of view of coordinating with other outputs or maximizing the time available for other activities.

4. Cost effectiveness.

How far / good organizational resources (eg human, monetary, technological, material) are maximized in the sense of obtaining the highest profit or a reduction in the loss of each unit, or examples of resource use.

5. The need for supervision. To what extent / is an employee able to carry out work functions without having to ask for supervisory assistance or require supervision intervention to prevent adverse results.

Thus, in measuring or assessing how well the performance of employees in the company can use these criteria as indicators.

\subsection{Framework}

a. The Effect of Organizational Culture on Employee Performance

Ronny and Susanti (2019: 37) state that organizational culture has a positive and significant effect on employee performance.

According to Uha (2013: 16), with organizational culture we can improve the behavior and motivation of human resources so as to improve performance and in turn improve organizational performance to achieve organizational goals.

According to Sutrisno (2015: 31), the socialization of organizational culture can provide benefits for employees to facilitate them in adjusting to the environment, work and other members of the organization, so as to foster employee commitment to the 
organization which ultimately is expected to be able to improve overall organizational performance .

\subsection{Effect of Training on Employee Performance}

According to Rivai and Sagala (2011: 212), training is very important for new employees and old employees. Training, briefly defined as an activity to enhance current performance and future performance. According to Sunyoto (2012: 140-141), one of the objectives of the training is to improve performance. Employees who work unsatisfactorily due to lack of skills are the main target of the training.

\subsection{Effect of Communication on Employee Performance}

According to Sopiah (2008: 142), communication serves to arouse employee motivation. This function works when managers want to improve employee performance for example the manager explains or informs how well the employee has worked and by how employees can improve their performance. According to Bangun (2012: 372), communication is one of the important tasks of managers to achieve good work results in organizations. Communication in the organization must go both ways, the leader communicates information clearly to the employees by using the right media. Instead employees must have the ability to receive work messages or information from their superiors.

\subsection{Hypothesis}

Based on the theory and frame of mind mentioned above, the hypotheses in this study are:

1. Organizational culture has a positive and significant influence on the performance of employees of PT. Multi Jaya Samudera.

2. Training has a positive and significant impact on the performance of employees of PT. Multi Jaya Samudera.

3. Communication has a positive and significant impact on the performance of employees of PT. Multi Jaya Samudera.

\section{Research Methods}

This research was conducted at PT. Multi Jaya Samudera which is located on Jalan Bagan Deli Lama No. 1 Belawan - Medan.

The study was conducted on all employees of PT. Multi Jaya Samudera which will become the population in this study. The population in this study amounted to 95 people. The sampling technique uses the census method.

The method used in this study is a survey method. In survey research methods, data are collected from samples of the population and use a questionnaire as a primary data collection tool (Singarimbun \& Effendi, 1995).

The survey method determined is explanatory survey, because it will explain the relationship between the variables studied (Cooper, 2005). The type of relationship between variables is causal, that is, the independent variable influences the dependent variable.

Explanatory research refers to the hypothesis theory that will be tested as the cause of the phenomenon. This phenomenon is seen in an object of research as a unit of analysis at PT. Multi Jaya Samudera. 
The study was conducted at a certain time (cross sectional) that reflects the phenomenon of a situation at a time in 2020. In accordance with its purpose, this study is to explain the causality relationship between research concepts and hypothesis testing in order to make decisions inductively or generatively, then research this is descriptive and verification.

Descriptive analysis that is describing the independent variables and the dependent variable which will be the basis of the theory or study of theory in research that contains the arguments or arguments of the variables studied. While the verification analysis is carried out to test the hypothesis by using a statistical test tool (Sekaran, 2005). In this study, the verification analysis used is the structural equation model (SEM) analysis tool. The measurement scale of the variable used in this study is a Likert scale.

Exogenous latent variable $(\xi 1)$ is organizational culture, exogenous latent variable

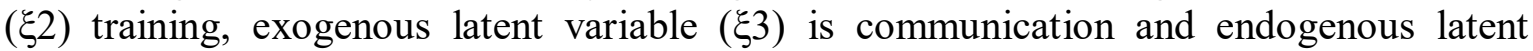
variable $(\eta 1)$ is employee performance. The model of this research is as follows:

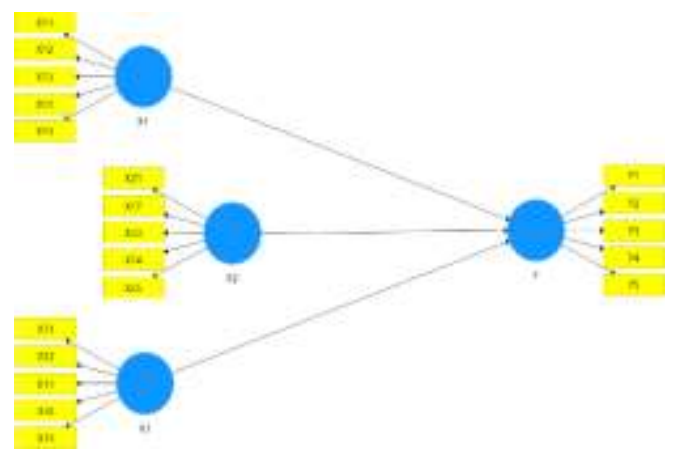

Figure 1. Research Model

To test the model and hypothesis used SEM. This research uses SmartPLS version 3.0 .

\section{Results and Discussion}

PT. Multi Jaya Samudera is a private company engaged in shipping and was established on April 2, 1997. The company is located at Jalan Bagan Deli Lama, Belawan.

The vision of PT. Multi Jaya Samudera is to become the best shipping company in Indonesia. The mission of PT. Multi Jaya Samudera is building an effective and professional company with human resources (HR) who care, dedicated and superior and provide the best service to business partners and customers.

The results of the descriptive statistical analysis were performed on each research variable, namely organizational culture, training, communication and employee performance. The descriptive statistical analysis provided is a description of the respondent's answers namely PT. Multi Jaya Samudera while the results of descriptive statistical analysis show that in general the organizational culture is in good condition with a mean value of 3.55 , training is in good condition with a mean value of 3.80 , communication in good condition with a mean value of 3.83 and employee performance in good condition with a mean value of 3.60 .

Inferential statistical analysis using structural equation modeling with the smartpls 3.0 application program consists of an analysis of the measurement model (outter model) and structural model analysis (inner model). 
The structural model of the research picture can be seen in Figure 2 below:

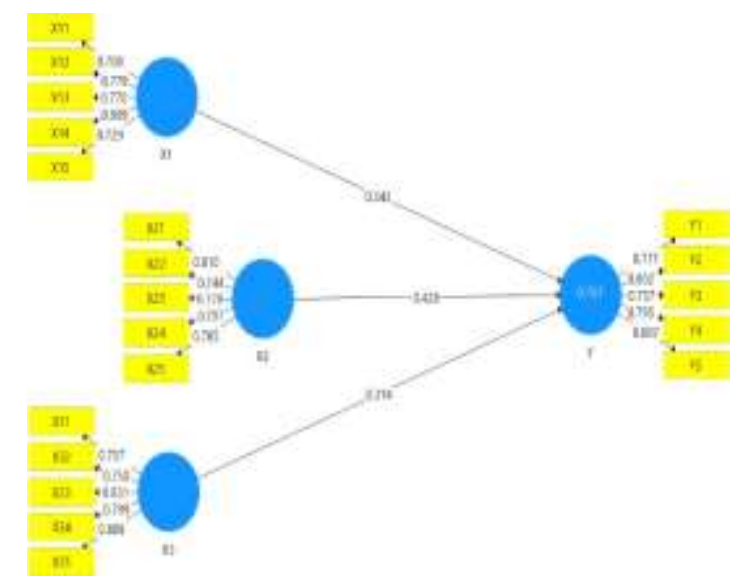

Figure 2. Structural Research Model

Analysis of the measurement model (outter model) consists of convergent validity, discriminant validity and composite reliability. Convergent validity assessment is done by looking at the Average Variance Extracted (AVE) value, where if the AVE value obtained is greater than 0.50 , then the indicator used has fulfilled the convergent validity (Hair et al, 2011). AVE values obtained in this study can be seen in table 1 below:

Table 1. Average Variance Extracted Value

\begin{tabular}{ll}
\multicolumn{1}{c}{ Variabel } & AVE \\
\hline Budaya Organisasi & 0,577 \\
\hline Pelatihan & 0,611 \\
\hline Komunikasi & 0,624 \\
\hline Kinerja Karyawan & 0,618 \\
\hline Source: Research Results, 2020 (Data processed)
\end{tabular}

Tabel 2. Cross Loading Score

\begin{tabular}{ccccc}
\hline Indicators & $\begin{array}{c}\text { Organizational } \\
\text { Culture }\end{array}$ & Training & Communication & $\begin{array}{c}\text { Employee } \\
\text { Performance }\end{array}$ \\
\hline X11 & 0,708 & 0,195 & 0,406 & 0,439 \\
X12 & 0,779 & 0,346 & 0,490 & 0,554 \\
X13 & 0,770 & 0,337 & 0,419 & 0,504 \\
X14 & 0,809 & 0,266 & 0,306 & 0,539 \\
X15 & 0,729 & 0,270 & 0,376 & 0,492 \\
\hline X21 & 0,263 & 0,810 & 0,438 & 0,578 \\
\hline X22 & 0,361 & 0,744 & 0,402 & 0,562 \\
\hline X23 & 0,382 & 0,770 & 0,405 & 0,520 \\
\hline X24 & 0,254 & 0,797 & 0,346 & 0,575 \\
\hline X25 & 0,218 & 0,785 & 0,359 & 0,552 \\
\hline X31 & 0,401 & 0,359 & 0,757 & 0,553 \\
\hline
\end{tabular}

Source: Research Results, 2020 (Data processed)

Table 2 shows that each indicator has the highest value of loading factor when it is connected to the intended construct compared to when it is connected with other constructs. 
The assessment of internal consistency reliability is done to test the reliability of each indicator. Internal Consistency Reliability is done by looking at the composite reliability value of the indicator block that measures the construct. The rule of thumb value of the composite reliability obtained must be greater than 0.70 (Ghozali, 2015). The results of composite reliability in this study can be seen in table 3 below:

Tabel 3. Composite Reliability

\begin{tabular}{|l|c|}
\hline \multicolumn{1}{|c|}{ Variable } & Composie Reliability \\
\hline Organizational Culture & 0,872 \\
\hline Training & 0,887 \\
\hline Communication & 0,892 \\
\hline Employee Performance & 0,890 \\
\hline
\end{tabular}

Source: Research Results, 2020 (Data processed)

Table 3 shows that the composite reliability value for all constructs is above 0.70 which states that all constructs in the estimated model meet the criteria for internal consistency reliability.

Structural model analysis (inner model), inner model analysis is done by estimating the path coefficient of the relationship between constructs. The value of the path coefficient on the relationship between variables becomes a reference in estimating. A positive value indicates a positive influence and vice versa a negative value indicates a negative effect. The greater the value of the path coefficient, the greater the influence between these variables. To find out the influence of exogenous variables on endogenous variables can be seen in table 4 as follows:

Tabel 4. Path Coefficient

\begin{tabular}{|c|c|c|}
\hline Effect & Path Coefficien t & P Value s \\
\hline Organization Culture $\longrightarrow$ Employee Perfromanc & 0,342 & 0,000 \\
\hline Training $\longrightarrow$ Employee Perfromance & 0,428 & 0,000 \\
\hline Communicatio $\mathrm{n} \longrightarrow$ Employee Perfromance & 0,314 & 0,001 \\
\hline
\end{tabular}

Source: Research Results, 2020 (Data processed)

Table 4 shows that in shaping employee performance, organizational culture, training and communication each has a positive influence.

The path equation in this study is as follows: $\mathrm{Y}=0.342 \mathrm{X} 1+0.428 \mathrm{X} 2+0.314 \mathrm{X} 3$ based on the above equation it can be seen that the path coefficient value for organizational culture variables of 0.342 indicates that organizational culture variables have a direct relationship with employee performance variables which means the better the application of organizational culture, the employee's performance will increase and conversely the lower the organizational culture, employee performance will decrease.

The path coefficient value for the training variable of 0.428 indicates that the training variable has a direct relationship with the employee performance variable which means the better the training, the employee's performance will increase and conversely the lower the training, the employee's performance will decrease.

The path coefficient value for the communication variable of 0.314 indicates that the work communication variable has a direct relationship with the employee performance variable which means the better the communication, the employee's performance will 
increase and conversely the worse the communication, the employee's performance will decrease.

The significance value that the value of $\mathrm{P}$ Values or the significance value of the influence between organizational culture variables on employee performance is 0,000 where the value of $\mathrm{P}$ Values or the resulting significance value is $<0.05$, it can be concluded that the influence between organizational culture variables on employee performance variables in this study was significant. The $\mathrm{P}$ Value Value or the significance value of the influence between the training variables on employee performance is 0,000 where the $\mathrm{P}$ Value Value or the resulting significance value is $<0.05$, so it can be concluded that the influence between the training variables on the employee performance variable in this study is significant, while the value of $\mathrm{P}$ Values or the significance value of the influence between communication variables on employee performance is 0.001 where the value of $\mathrm{P}$ Values or the resulting significance value is $<0.05$, it can be concluded that the influence between communication variables on employee performance variables in this study is significant.

The results of the calculation of the coefficient of determination (R Square Adjusted) using SmartPls 3.0 for contributions between variables of organizational culture, training and communication of employee performance variables are 0.749. This shows that the contribution of organizational culture, training and communication variables to improve employee performance is 0.749 or $74.9 \%$, while the rest of 0.251 or $25.1 \%$ influenced by other variables not examined in this study.

\section{Conclusion}

Based on the results of descriptive analysis for organizational culture variables, training, communication and employee performance at PT Multi Jaya Ocean is in good category. Organizational culture has a positive and significant effect on employee performance at PT. Multi Jaya Samudera. That is, the better the application of organizational culture, the higher the performance of employees Training has a positive and significant effect on employee performance at PT. Multi Jaya Samudera. That is, the better the training, the higher the employee's performance Communication has a positive and significant effect on employee performance at PT. Multi Jaya Samudera. That is, the better the communication the higher the employee's performance

\section{Suggestion}

It is hoped that PT Multi Jaya Samudera can increase the internalization of organizational culture by applying values the value of the company consistently, especially the value of the first priority to safety. As with regular socialization and safety training to each employee. It is expected that PT. Multi Jaya Samudera can improve the quality of training provided to employees by ensuring that trainers / instructors have good competence and are able to deliver training effectively. It is expected that PT. Multi Jaya Samudera can increase the effectiveness of communication within the company by ensuring the accuracy of the method communicate according to the characteristics of the employee (message recipient) as to employees who have a low level of education using sentences that are simple and easy to understand. For further researchers it is recommended to conduct research using other independent variables that have not been examined in this study, such as leadership, competence and work motivation. 


\section{References}

AA. Anwar Prabu Mangkunegara. (2013). Manajemen Sumber Daya Manusia Perusahaan. Bandung: Remaja Rosdakarya.

Dessler, Gary. (2011). Manajemen sumber daya manusia. Penerbit Indeks, Jakarta.

Ghozali, I. (2013). Aplikasi Analisis Multivariate Dengan Program IBM SPSS 21 Edisi 7.

Semarang: Badan Penerbit Universitas Diponegoro.

Hair, J. F., \& E., a. A. (2014). Multivariate Data Analysis. Pearson Prentice Hall, New Jersey, 7 th ed.

Hamalik, Oemar. (2007). Manajemen Pengembangan Kurikulum, Bandung: PT. Remaja Rosda Karya.

Kaswan. (2012). Manajemen Sumber Daya Manusia untuk Keunggulan Bersaing Organisasi. Yogyakarta: Graha Ilmu.

Purwanto. (2011). Evaluasi Hasil Belajar. Yogyakarta: Pustaka Pelajar.

Rivai, Veithzal dan Sagala, Ella Jauvani. 2011. Manajemen Sumber Daya Manusia untuk Perusahaan dari Teori ke Praktik. Jakarta: PT Raja Grafindo.

Ronny, Yusuf Edward.(2020). Manajemen Sumber Daya Manusia Sebuah Pengantar,Medan:Gerhana Media Kreasi. Ronny, Yusuf Edward dan Susanti. 2019. The Effectof Organizational Culture and Work Motivation on Employee Performance with Job Satisfaction as an Intervening Variable at PT. Berkat Bima Sentana. IOSR Journal of Business and Management.Volume 21, Issue 11. Series. III November, 2019:31-38.

Sopiah. (2008). Perilaku Organisasi, Yogyakarta: Andi Offset.

Sutrisno, H. Eddy. (2015). Manajemen Sumber Daya Manusia. Jakarta: Kencana.

Syardiansah. (2020). The Effect of Job Satisfaction and Organizational Culture on Employee Performance of the Royal Hotel in East Aceh District. Budapest International Research and Critics Institute-Journal (BIRCI-Journal). P. 849-857.

Umam, Khaerul. (2012). Manajemen Organisasi. Bandung: Pustaka Setia.

Yani, M. (2012). Manajemen Sumber Daya Manusia. Jakarta: Mitra Wacana Media. 